\title{
TÁRSADALMI FOLYAMATOK BUDAPEST KÖZIGAZGATÁSI HATÁRÁNAK KÉT OLDALÁN
}

\author{
(Social processes on the both side of the administrative boundary of \\ Budapest)
}

\section{IZSÁK ÉVA}

\section{MOTTÓ:}

"Ma már tudom, hogy határszélen laktunk. Persze a szónak nem szokásos, hanem társadalmi értelmében, a város és külváros között (...) Délelött délnek indultam, a Belváros felé, ahol az iskolában a polgári társadalom nevelt, délután északnak indultam, a Népház kölcsönkönyvtára felé... Még a szaga is más volt az utcának a házunktól északra, mint a házunktól délre, s a belvárosi iskola és a külvárosi kölcsönkönyvtár szagkülönbségein közvetlenül észlelhettem, szinte naponta, hogy az emberi egyenlőség csak a halál után kezdődik."

(Szabó Zoltán)

\section{Bevezetés}

A fenti idézet szerzóje a város és vidéke közötti különbségeken elmélkedik, miközben arra készteti olvasóját, hogy elgondolkodjon: milyen is valójában az a társadalmi környezet, amely körülveszi? Vannak-e ma is ilyen "érzékszervekkel" tapasztalható különbségek a nagyváros és közvetlen környezete között?

Az emberek által lakott tereknek vannak olyan részei, ahol nehezen határozható meg az, hogy hol ér véget a társadalmi cselekvéseik színtere. Gondoljunk csak egy nagyobb település-tömörülésre, nagyváros körüli szomszédságra, vagy egy fơvárosi agglomerációra, ahol annak megállapítása, hogy hol ér véget a lokális tér, az a társadalmi környezet, amelyben az egyének, csoportok élnek, szinte lehetetlen feladat. Sokkal bonyolultabb kölcsönhatások is megtalálhatók egy-egy ilyen település-halmaz esetében. Éppen ezért nem egymástól elszigetelt egységeket kell vizsgálni, hanem egy olyan rendszert, amelyben a tagok, a települések egymás mellett, egymással párhuzamosan és egymásra jelentős befolyást gyakorolva léteznek. Ezek már olyan kölcsönhatási viszonyok, amelyeknek hatása nemcsak a közigazgatásilag meghatározott térben - azaz a település határain belül érvényesülnek - , hanem azoktól távolabb is.

A települések fejlődése maga után vonja térbeni növekedésüket, az egymáshoz való földrajzi közeledésüket is. Kapcsolat alakul ki közöttük, az emberek elkezdenek "átjárni" a szomszédos településre, munkát vállalnak ott. Közlekedési útvonalak épülnek ki, és a kölcsönhatás egyre inkább erősödik, tekintet nélkül a telepullés hivatalosan meghatározott kơzigazgatási határára. 


\section{A FÖVÁROS HATÁRMENTI TERÜLETEINEK NÉHÁNY JELLEGZETES VONÁSA ÉS EZEK VIZSGÁLATA}

Az 1949. évi XXVI. törvény, mely "Budapest föváros területének új megállapításáról" rendelkezik, 23 települést' csatolt a fövároshoz, amelyek önállósága ezáltal megszünt és egy egészen új fejlődési útra tértek át, mely maga után vonta a környező települések fejlődését.

Az urbanizációs folyamatnak ebben a szakaszában a városok környéke, így a föváros szomszédos települései is leginkább azáltal fejlödtek, hogy a központi település köré, annak szomszédságába óriási munkavállalói tömegek költöztek, fơként a centrum rendkívül gyors iparosítása miatt. Mivel Budapesten a közigazgatási határon belül korlátozták a beköltözést, a munkavállalók nagy többsége ezért annak külső oldalán telepedett le. A 23 szomszédos település bekebelezése nyomán egy egészen különleges zóna alakult $\mathrm{ki}$ a föváros közigazgatási határa mentén: annak belső oldalán olyan területrészeket találhatunk, melyek a centralizált és egyoldalú település-fejlesztés elött még nem tartoztak a fövároshoz, annak csupán közvetlen szomszédai voltak. A másik oldalon pedig olyan települések sorakoznak, melyeket a közigazgatási reform nyomán Budapest közvetlen szomszédai lettek. A határmenti területek tehát nagyon sok új információt adhatnak a Budapest környéki területek fejlödéséről, valamint arról, hogy a fövároshoz való tartozás milyen előnyökkel járt. További érdekessége a területnek, hogy az 1950-ben becsatolt területek ugyanazt a funkciót töltötték be a föváros határán kívül, mint a ma ott sorakozó 23 település.

1950-töl kezdve tehát a két rész eltérően fejlödött, elsősorban amiatt, hogy az anyagi javak jelentős részét a fơváros közigazgatási területére összpontosították. Így az azóta eltelt évtizedek alatt jelentős különbségek alakultak ki a két területrész között.

$\mathrm{Az}$ eltérő fejlődés és fejlesztés ${ }^{2}$ következtében kialakult hasonlóságok és különbségek vizsgálata a föváros és környékének településein elengedhetetlenül szükségesek ahhoz, hogy az itt lezajló társadalmi folyamatokat értelmezzük. Abból a feltételezésből indulunk ki ugyanis, hogy a föváros vitathatatlan befolyása nem egyenletesen érvényesült sem az új határokon belülre került települések, sem pedig az e folyamat keretében szomszédokká vált települések irányában. Nem elegendő a föváros és egy-egy település, vagy az egész agglomeráció társadalom-földrajzi, szociológiai vizsgálata. Mindenképpen szükséges egy ennél árnyaltabb, kisebb területre kiterjedő elemzés is. Ennek egyik lehetséges módszere a település és a vele szomszédos fövárosi kerület, vagy egyes részeinek összehasonlító jellemzése. Ebben az esetben olyan település-párokat vizsgálunk, amelyek fejlödése hasonló utat jár be, ugyanakkor jól szemléltethetỏ az is, hogy a fövároshoz való tartozás milyen változásokat okozhat. A kiválasztott területen, a föváros határának két oldalán zajló folyamatok ugyanakkor arra is rámutathatnak, hogy a közigazgatási határ nem minden esetben jelent valódi határt a két területrész között. Az egyes társadalmi mozgásfolyamatok, jelenségek más határokat is megszabhatnak, kialakíthatnak, hiszen ez az átalakulás nemcsak a határon belül eső területeken tapasztalható 1950 óta, hanem a határon kívül eső részeken is.

A három mintaterület (északnyugati, északi és délkeleti) a föváros és környékének három jellegzetes, egymástól eltérő fejlődésü része. Az elemzés során a kerület, mint vizsgálati egység nem bizonyult jó megfigyelési egységnek. Az 1950-ben csatolt települések ma is 
jól körülhatárolhatóak a városrendezési körzetekkel. Így az egykor önálló telepủlések a fóvárosba beolvasztva, városrendezési körzeti szinten vizsgálhatók.

Jelen munka arra tesz kísérletet, hogy jól körũlhatárolt mutatók segítségével bemutassa azt a jelenlegi állapotot ${ }^{3}$, amely már jól tükrözi a közigazgatási reform óta eltelt 40 esztendỏ változásait. A vizsgálathoz használt három mutató (demográfia, iskolázottsági szint, lakó-, és lakáskörülmények) alkalmasak arra, hogy a térbeni-társadalmi különbségeket bemutassák.

Egy terület fejlettségét nagymértékben meghatározzák az ott lezajló demográfiai folyamatok. A korösszetétel, a tẹrmészetes szaporodás, az aktív-inaktív arány mind olyan mutató, amelyekkel jól leírható egy terület társadalmának fejlettsége demográfiai szempontok alapján. A népesség mennyiségi jellemzőinek változása sok esetben maga után vonja a minóségi változást is, amelynek bemutatására az iskolázottsági szint változásának vizsgálata kiválóan alkalmas. Az agrár-, illetve ipari térségek, továbbá ezzel párhuzamosan a falu-város viszonylatában lezajlott népességmozgás egyidejúleg a munkaerő képzettség szerinti megoszlásában is éles területi differenciálódást eredményezhet. A település vagy településrész fejlettségét nagymértékben meghatározza az, hogy milyenek az ott élök lakás-, és lakókörülményei. A lakókörnyezet mennyiségi és minőségi jellemzői befolyásolják a benne élók magatartását. Így elkerülhetetlen; hogy bevonjuk a vizsgálatba a lakással kapcsolatos mutatókat is.

\section{II. kerület, Solymár, Nagykovácsi}

Bủdapest II. kerülete, valamint a vele szomszédos két település, Solymár és Nagykovácsi a fóváros és környékének észak-nyugati oldalán helyezkedik el. Földrajzi fekvését tekintve a fỏváros talán legszebb természeti kömyezete. A Budai-hegység vonulatai, az általuk közrefogott Pesthidegkúti-medence és az Ördög-árok tektonikus súllyedéke tagolja a területet. Nagy-Budapest létrehozásakor a kerülethez csatolták Pesthidegkút községet, s igy jött létre a mai II. kerület.

Pesthidegkút (219.,220. sz. vrk.) már a középkorban is lakott volt (Hidegkút néven). Az elmúlt évszázadokban jelentős volt a német ajkú lakosság letelepedése a faluban. Lakosai főként mezőgazdasággal foglalkoztak, kiemelkedő volt a falu és környékének szőlökultúrája. A település régi központja a mai napig fennmaradt. Ettől távolodva a legújabbkori parcellázások következtében elsősorban a Budapestről kiköltőzők telepedtek le, megváltoztatva ezáltal a település korábbi, falusias jellegét. A mezógazdaságban dolgozók száma egyre csökkent, s nỏtt a fỏváros belső területeire ingázó, az iparban illetve a tercier szektorban dolgozók aránya.

Nagykovácsi község Budapesttől északnyugatra található, a Nagy-Kopasz hegy erdős és a Nagy-Szénás kopár vonulata közötti medencében. A föváros környékének legmagasabban fekvö települése $(342 \mathrm{~m})$.

Solymár Nagykovácsitól északra fekszik. A település már a középkorban is lakott, Mátyás király idejében vadaskert volt itt. Lakosai elsősorban állattenyésztéssel és gyümölcstermesztéssel foglalkoztak, majd a múlt században téglagyárat létesítettek az itt található kőbánya mellé.

A fóváros második kerületében a demográfiai adatok jelentős területi eltéréseket mutatnak. Az 1950-ben a kerülethez csatolt pesthidegkúti területeken az "öslakosság" jelenlétét jól tükrözi az idősebb korosztály (60 éves és idősebb) magasabb aránya. Elhagyva a jelenlegi közigazgatási határt a korcsoportok megoszlása teljesen megváltozik. 
A Budapest környéki településekre - különösen a Budai oldalra - való kitelepedés az ott élő népesség megfiatalodásával jár, hiszen a fiatalabb korosztályok általában sokkal mobilabbak, s ök azok, akik új lakóhelyet keresve kitelepednek a föváros környékére. Ez tapasztalható Solymár illetve Nagykovácsi esetében is. A két település népessége az elmúlt harminc esztendö alatt lassan és egyenletesen növekedett. Solymáron valamivel gyorsabban nőtt a lakónépesség, mint Nagykovácsiban, mivel Nagykovácsi később kapcsolódott be a fövárosból kitelepedő népesség befogadásába, elsősorban kedvezőtlenebb földrajzi fekvése miatt. ${ }^{4}$ A demográfiai adatok bizonyítják, hogy a két község, Solymár és Nagykovácsi az elmúlt évtizedekben közkedvelt lakhelyévé vált a fövárosból kitelepedő népességnek. Ezt természetesen nemcsak a népesedési folyamatok mutatják meg számunkra, hanem a lakások számának és minőségének változása is.

A legtöbb régen épült lakás a 219. számú városrendezési körzetben található. Ez a terület Pesthidegkút régi faluközpontja. Nagykovácsi községben szintén magasabb az idősebb lakások aránya, míg Solymár és Pesthidegkút 220. sz.vrk-ben valamivel kevesebb az 1945 elött épült lakás. 1945 és 1959 között viszonylag kevés lakás épült a területen, ezt követően indultak meg az építkezések a településeken. A legtöbb új lakás Pesthidegkúton található. Az adatok nagyon jól példázzák Budapest és környékének fejlödését. Addig, amíg a föváros belső területén voltak beépítésre alkalmas területek, addig annak határain kívül lassabb volt az építkezési ütem. Pesthidegkúton igen sok területet parcelláztak ki és adtak el az egyesítést követően. Ennek köszönheti Pesthidegkút mai kettős arculatát is. A megmaradt régi faluközpont köré épültek a modern, fiatal lakások. Ahogy a fövárosban rohamosan csökkentek a szabad, beépitésre alkalmas területek, megindult a szomszédos községekbe való kiköltözés. Elöször Solymárra, majd valamivel később Nagykovácsiba (a korábban már említett "kedvezőtlenebb" földrajzi elhelyezkedés miatt).

A lakások komfortossági mutatóit az 1. ábra mutatja. Az ábrán nagyon jól láthatóak a területi különbségek a második kerület egyes részei között. Az 1950-ben csatolt pesthidegkúti területen sokkal kisebb a komfortos és összkomfortos lakások aránya ${ }^{5}$, mint a kerület többi részén. Solymár és Nagykovácsi adatai is a pesthidegkúti arányokat mutatják. A föváros környéki, illetve az 1950-ben a fövároshoz csatolt területek lakásminöség szempontjából hasonló helyzetben vannak. A közmüellátottság fejlödése ezeken a részeken késóbb indult meg, mint a föváros belső területein, így a lemaradás jelentős. Az új parcellázások, a fơvárosból kiköltözők magas aránya kedvez a gyorsabb fejlődésnek, s várhatóan a különbség csökkenni fog. Egyre inkább eltünik a települések falusias jellege, ami nemcsak a lakások minöségi javulásán mutatkozik meg, hanem a telepulések lakosságának növekedésében is.

A 1. ábra a diplomások arányát ${ }^{6}$ mutatja. A területi eltérés itt is szembetúnő. A diplomások arányát tekintve a föváros legmagasabb státusú területei közé tartozik a II. kerület. A kerületi átlagok jóval meghaladják a föváros bármely más területének adatait. Nincs még egy olyan terulete Budapestnek, ahol minden területi egységben $25 \%$ feletti a diplomások aránya. Hasonló a helyzet Solymár és Nagykovácsi adataival: a budapesti agglomeráció településein nem találunk ilyen magas diplomás arányt. A fövároshoz való közelség nagymértékben meghatározhatja, hogy az egyes településeken milyen arányú a magasabban képzettek jelenléte. A budapesti agglomeráció nyugati, északnyugati része leginkább a fövárosból kiköltözö csoportoknak vált lakhelyévé az elmúlt évtizedekben, $\mathrm{s}$ elsősorban az iskolázottabbak telepedtek itt le. A szabad telkek beépítése az agglomeráció más részein nem tapasztalt gyors ütemben folyt és folytatódik a mai napig.is, és nemcsak a lakások minőségének a javulását eredményezi, hanem a lakosság átstrukturálódását is. 


\section{1. ÁBRA}

A II. keriulet és a határos települések jellemzöi (Some elements of the $2^{\text {nd }}$ district of Budapest and surrounding settlements)
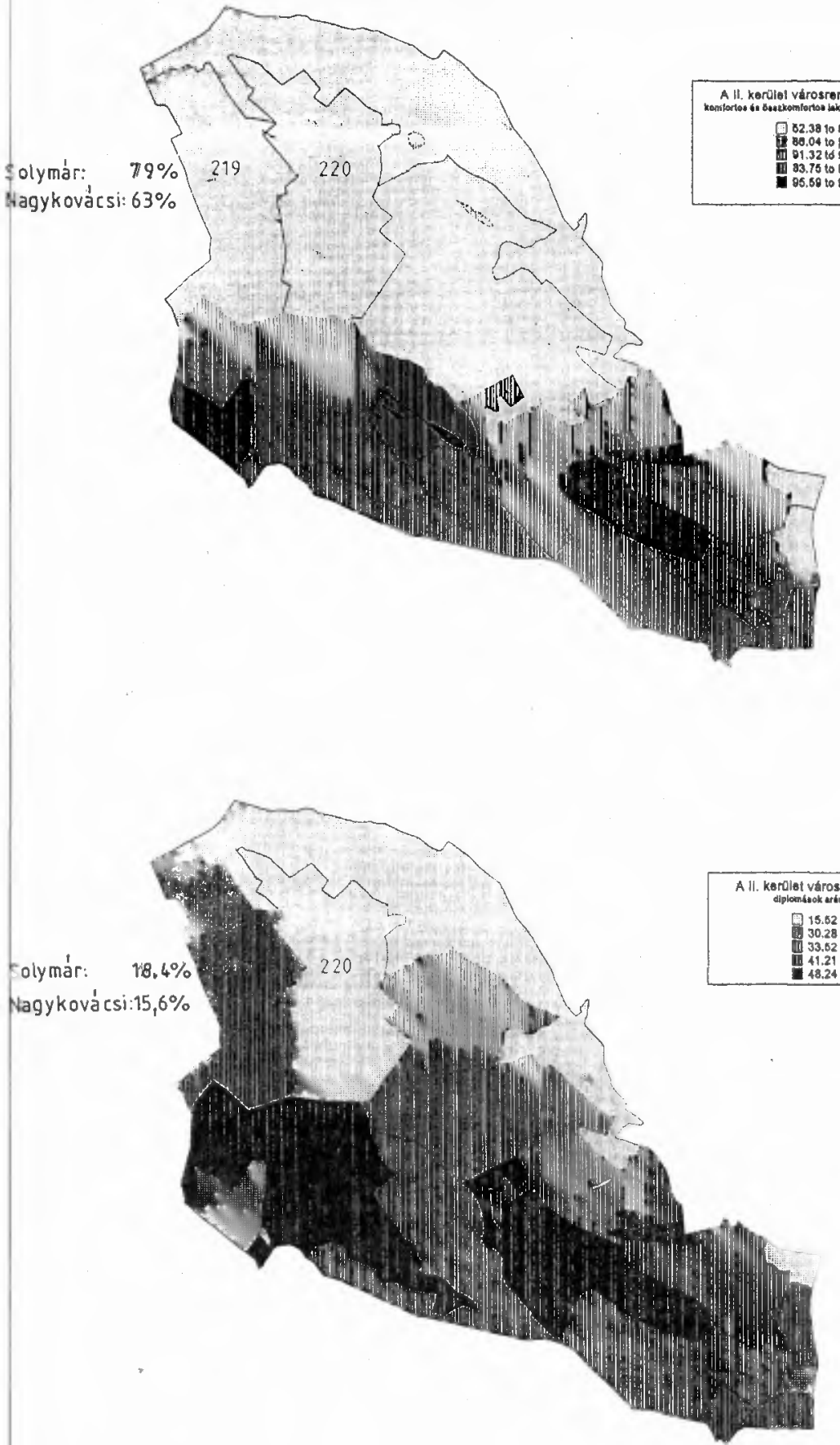


\section{2. ÁBRA}

A IV. kerület és Dunakeszi jellemzöi

(Some elements of the $4^{\text {th }}$ district of Budapest and Dunakeszi)
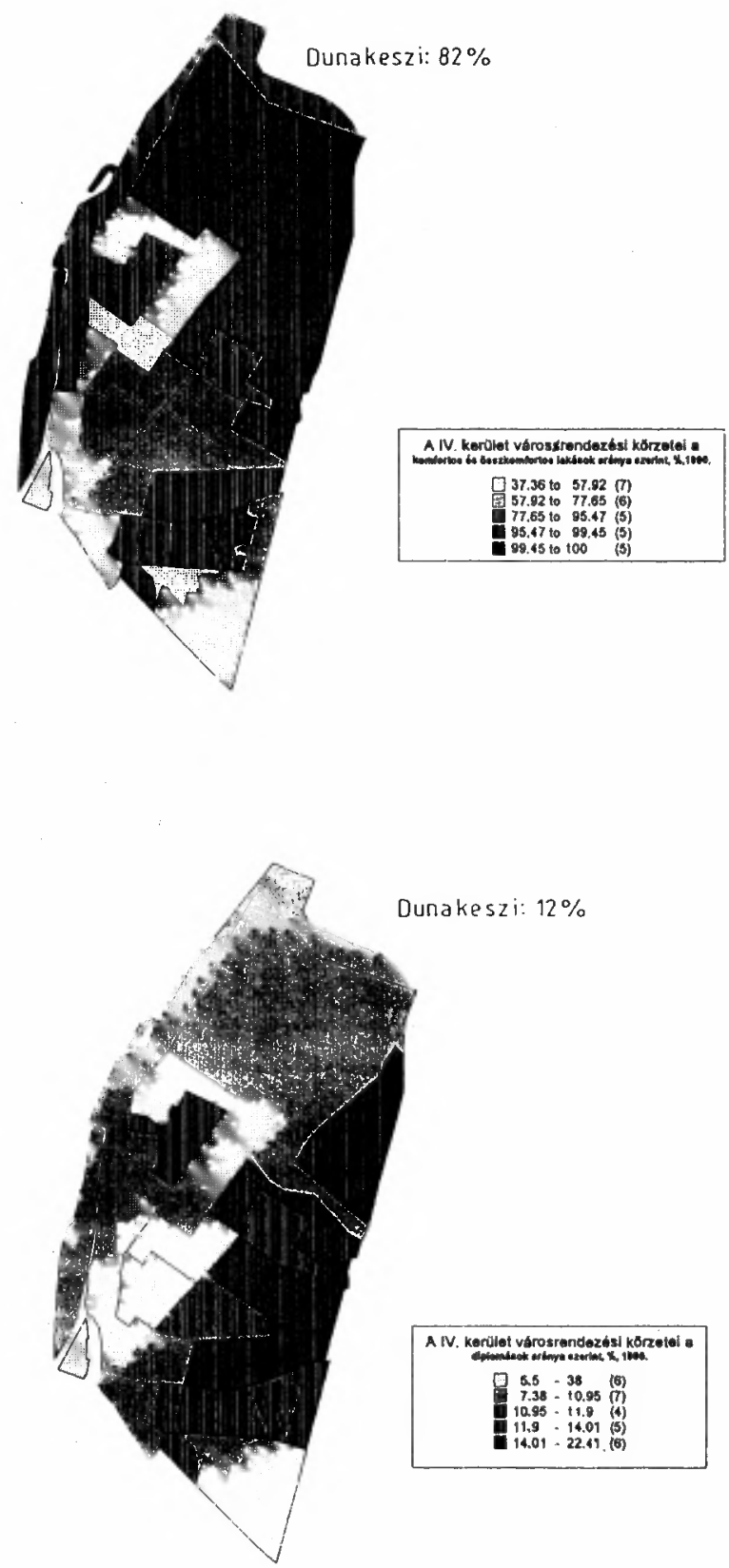
Az agglomeráció és a föváros északnyugati régiója egy dinamikusan változó terỉlet. Fejlődése leginkább az amerikai nagyvárosok körüli települések fejlödésére hasonlít. A fơvárosból a magasabban iskolázott rétegek költöznek ki a területre, munkahelyet nem, csak lakóhelyet változtatva. A térség dinamikus fejlödéséhez nagymértékben hozzájárul a természeti környezet jó minősége is, valamint a fővároshoz való közelség. A közlekedési infrastruktúra, a fỏvárosból kijáró kék busz, illetve a közúti közlekedést szolgáló fớtvonalak sokáig elegendőnek bizonyultak. A terỉlet lakossága azonban oly mértékben nö, hogy hamarosan súlyos gondok jelentkezhetnek a közlekedésben. Ennek ellenére a területröl elmondható, hogy a föváros és környékének sehol másutt nem tapasztalható gyors fejlődésen ment és megy keresztül. Az 1950-ben becsatolt pesthidegkúti terület egyre jobban beilleszkedik a II. kerület többi részébe. A hasonló mutatók azt bizonyítják, hogy rövidebb-hosszabb időn belül a két szomszéd település, Solymár és Nagykovácsi is szerves része lesz Budapest északnyugati régiójának, tekintet nélkủl a meglévö közigazgatási határra.

\section{Budapest IV. kerület, Dunakeszi}

A fơváros és környéke fejlődésének az előzőekben látott terủlethez képest egészen más típusát képviseli az északi régió. Az egykori Újpest, ma a fóváros IV. kerülete, és a vele szomszédos Dunakeszi történelmi-gazdasági fejlödése eltér egymástól. Újpest a múlt század elején még ritkán lakott település volt. Népessége a XIX. sz. második felében kezdett el ugrásszerủen gyarapodni, s így a századfordulóra elérte a 40000 fót. A gyors fejlődés elsősorban az ide telepedő iparnak köszönhető, valamint annak, hogy a telepủlés hagyon kedvező közlekedés-földrajzi helyen található. A Duna menti térség hozzájárult az ipartelepítéshez, mely a század első évtizedeiben egyre gyorsuló ütemben tovább folyt (Ólomgyár, Cérnagyár, Gyógyszergyár stb.). A fóvároshoz történő csatlakozás már a századfordulón felmerült, de végül megyei jogú városi rangot kapott Újpest. A foóvároshoz 1950-ben csatolták a települést, s ez tovább gyorsította a fejlödést. Hatalmas ipari uizemeket létesítettek itt, s a főváros duzzadó népességének befogadására két ütemben mintegy 15000 lakást adtak át ${ }^{7}$. Újpest tehát az elmúlt száz év alatt fejlödött, s ennek a fejlődésnek a legjellemzőbb tulajdonsága a városiasodás volt. Ma már ez a kerület is kétarcú, mivel az egykori megyei jogú város magja a mai napig fennmaradt, és köré épült ki a fóváros egyik legjelentősebb ipari területe és hatalmas lakótelepek. Az Újpesttel szomszédos Dunakeszi egy egészen más fejlődésen ment keresztül. Lakosai inkább mezőgazdasági termeléssel foglalkoztak. A Duna által lerakott hordalék jó termőföldként szolgált a szőlő-, és gyümölcstermeléshez. A település fejlődése akkor gyorsult fel, amikor az 1980-as évek elején átadták a Dunához közel eső területen épült lakótelepet. A lakosság száma ugrásszerủen nött és bövültek a szolgáltató intézmények is. Hasonlóan az elózőekben bemutatott északnyugati terůlethez, a lakosság nagy része itt is ingázó.

A föváros és környékének északi terïlete különböző részekból áll. Éppen ezért nehéz a hasonlóságok és különbségek párhuzamba állítása.

A terület fent elemzett fejlődését tükrözik a demográfiai adatok is. A föváros IV. kerülete demográfiai szempontból is két részre osztható: a lakótelepi területeken sokkal magasabb a fiatalok aránya, mint a kerület többi részén, a régi városközpont fennmaradt részein. (Ez utóbbi részeken magasabb az időskorúak aránya, mint a lakótelepeken.) A Káposztásmegyeri lakótelepen a 24 évesnél fiatalabb korcsoport a lakosság 51\%, és itt a népesség mindössze $3 \%$-a idősebb 60 évesnél. Dunakeszin ${ }^{8}$ a lakosság 
korcsoportmegoszlása annyiban tükrözi a település fejlődését, hogy az új lakótelepre elsősorban fiatalok költöztek ki, s ez némileg kiegyenlitette a korcsoport-megoszlást.

Dunakeszin a lakások építési üteme az elmúlt évtizedekben viszonylag egyenletesnek mondható, az 1945 elött épült lakások aránya $26 \%$ és azóta is két évtizedenként átlagosan 25\%-kal nőtt a lakásállomány. Újpesten, a lakótelepeket nem számítva (ezek építése 196080 között, Káposztásmegyer pedig 1980-90 között történt), a lakások átlagéletkora elég magas. A lakott területen mindenütt meghaladja a $60 \%$-ot azon lakások aránya, melyek 1945 elött épülttek. Ezek a számok tovább erősítik a kerület kettős arculatát: a lakótelepek fiatalosak, modernek, míg a kerület többi részében a nagyon öreg lakásokban idős lakók élnek. A nem lakótelepi részeken 1945 óta alig épült új lakás.

A lakótelepeken mindenütt összkomfortosak a lakások (2. ábra), míg a kerület egyéb részein nagyon alacsony az összkomfortos lakások aránya, alig haladja meg a 20\%-ot. A komfortos lakások aránya már magasabb, átlagosan $40 \%$, de a komfort nélküli lakások aránya is nagyon magas, átlagosan a lakásoknak $30 \%$-a nem rendelkezik semmilyen komforttal.

A kerület lakásviszonyai tehát meglehetősen egyenlőtlenek. A kerület lakásállományának fejlesztését 1950 után lakótelep-építéssel oldották meg, s így maradt a kerületnek egy olyan része, ahol nagyon rossz minőségü, öreg lakások vannak. Az újpesti lakótelepépités, annak ellenére, hogy nagyon sok lakást építettek néhány évtized alatt, nem oldotta meg a helyi lakásproblémákat. A lakótelepi lakások elosztása fővárosi szinten történt, így a már korábban is ott élök lakásproblémái továbbra is megmaradtak. Az újonnan épült lakótelepekre pedig a föváros minden részéböl költtöztek.

Dunakeszin a lakások 82\%-a komfortos vagy összkomfortos, ami budapesti viszonylatban is igen jó. A lakások mindössze $8 \%$-a nem rendelkezik semmilyen komforttal. Bár a lakások 25\%-a itt is 1945 elött épült, de ezek egy részét komfortosították, s így a település lakásainak komfortossági mutatói viszonylag jók. A. lakótelep-építés itt is befolyásolta ezt, de a település többi részén is kiegyenlítettebb viszonyokat találunk, mint Újpesten.

A korábban tapasztalt kettősséget a legmagasabb iskolai végzettség adatai nem tükrözik ennyire egyértelmüen (2. ábra) viszonylag kiegyenlített a területen élök legmagasabb iskolai végzettsége. A lakosság többsége érettségivel, vagy általános iskolai végzettséggel rendelkezik. A lakosság 20\%-a érettségizett, 30\%-a nem rendelkezik általános iskolai végzettséggel. A diplomások aránya fövárosi összehasonlításban közepesnek mondható, átlagosan minden tizedik 24 évnél idősebb lakos rendelkezik egyetemi vagy föiskolai diplomával. A szomszédos Dunakeszin hasonlóak az arányok, a lakosság 12\%-nak van felsöfokú végzettsége, $31 \%$-a nem végezte el az általános iskolát, $25 \%$ érettségizett.

A föváros és környékének északi része az agglomeráció fejlödésének egyik sajátos példája. Nagy-Budapest létrehozása drasztikusan megváltoztatta a korábban fennálló viszonyokat. Újpestre hatalmas ipar települt, lakótelepeket építettek a fỏvárosi lakosság elhelyezésére, ugyanakkor a nem szanált területeken fennmaradt a korábbi településmag. A szomszédos Dunakeszi intenziven fejlödö település, minden olyan adottsággal rendelkezik, ami egy kisebb, regionális alközpont kialakításához szükséges. Mindemellett sokkal inkább alvóváros jellege van a településnek, a lakosság jelentős része a fövárosba ingázik mindennap. A közigazgatási reform, mellyel Újpest elvesztette önállóságát jelentősen befolyásolta a terület fejlődését. A hatalmas ingázó tömeg ${ }^{9}$ lehetetlenné teszi a fỏvárostól való fúggetlenedést, annak ellenére, hogy a fennmaradt régi településmag rendelkezik azokkal a funkciókkal, melyek az önállóvá váláshoz szükségesek. Dunakeszi 
pedig alkalmas lenne egy önálló Újpest esetén az elővárosi funkcióra is. Dunakeszi "hasonulása" a szomszédos kerülethez kisebb mértékben figyelhetô meg, mint az északnyugati területen.

\section{Budapest XVIII. kerület, Vecsés, Gyál}

A fơváros XVIII. kerülete két település - Pestszentlörinc és Pestszentimre - Budapesthez csatolásával jött létre. Pestszentimre (1823. 1824. 1826. vrk) 1930-ban a Soroksártól történő elválás után lett önálló település. Lakossága a századforduló környékén kezd el duzzadni, amikor Kispest határába gyáripart telepítettek, s ezzel megindul a munkástelep kiépullése. Az 1930-as önállóvá váláskor a lakosság több, mint 60\%-a gyáripari munkás. Pestszentlőrinc (1819. 1820. 1821.vrk) Kispest határának felparcellázásával alakult ki a múlt század végén. Ekkor több száz családi ház épült a területen. 1908-ban lett önálló. A telepes építkezés egészen a század közepéig fennmaradt (Szemere-, Rendessy-, Rokkant-. stb. telep). 1950 után több lakótelep is épült a kerületben (KISZ, Havanna), s a fỏvároshoz történỏ csatolás "következménye" lett a repülötér (Ferihegy 1,2), valamint a fỏváros egyik szeméttelepének kialakítása is. A két szomszédos település fejlődése egymástól eltérő jellegzetességeket mutat. Vecsés már a múlt században is jelentős mezőgazdasággal rendelkezett, s hosszú ideig a pestszentlörinci közigazgatási egységhez tartozott. ${ }^{10}$ Gyál történelme nem tekint hosszú múltra vissza. Népessége csak az elmúlt évtizedekben nótt rohamosan, a rendkívüli mértékủ beköltözés miatt. ${ }^{11} \mathrm{~A}$ betelepedést és a történelmi fejlödést tükrözik a demográfiai adatok is, mivel a régi lörinci, imrei és vecsési területeken magasabb az időskorúak aránya, míg Gyálon és a kerületi lakótelepeken sokkal több fiatal él.

A terület lakásainak komfortosságát az 3. ábra mutatja be. Jól látható az az Újpestnél már tapasztalt kettősség, amely a lakótelepi és a hagyományos, régebben épített lakások között fennáll. Az egykori Pestszentlörinc és Pestszentimre területén kevéssé komfortosak a lakások, mint a kerület egyéb ủjabban épült területein. Vecsés adatai a lörinci és imrei adatokhoz hasonló, de Gyálon sokkal rosszabbak a lakáskörülmények, annak ellenére, hogy az itt épült lakások újabbak, mint az elỏzó három telepủlésen levök. A diplomások aránya (3. ábra) a XVIII. kerület belsỏ oldalán magasabb, mint a kúlsó teruleteken, ami magyarázható egyrészt a lakótelepekkel, másrészt a föváros központi területéhez való közelséggel is. A történelmi teruleteken (Pestszentimre, Pestszentlörinc) alacsonyabb a diplomások aránya, de itt is területi különbségeket találunk. A legalacsonyabb a diplomások aránya az egykori Pestszentimre területén. ${ }^{12}$ Vecsés inkább hasonlít a lörinci és imrei területekhez, mint Gyál, ahol a fóvárosi agglomeráció egészét tekintve is a legalacsonyabb a diplomások aránya.

A fent bemutatott délkeleti része az agglomerációnak a korábbiaktól eltérô harmadik jellegzetes sajátosságokkal bíró területe. A korábban - 1950 előtt - együtt fejlődỏ Pestszentlorinc, Pestszentimre és Vecsés a mai napig is megörizte közös jellemvonásait, míg Gyál a fiatal település ettől eltérő tulajdonságokat mutat. A Szendy Károly által képviselt elképzelés, miszerint Vecsés fơvároshoz csatolása indokolt lenne a mai napig is megállja a helyét. A közigazgatási határ ebben az esetben nem tükrözi a telepủlések közötti kủlönbségeket. Az 1950-es csatlakozás nem gyorsította fel a fejlödést oly mértékben, mint az a budai területen tapasztalható volt. Ennek egyik oka nyilván az, hogy az a terület, amelyhez Vecsés, Pestszentlórinc és Pestszentimre felzárkózhat, korábban sem volt nagyon fejlett része Budapestnek. 


\section{3. ÁBRA}

A XVII. Kerület és a határos települések jellemzöi

(Some elements of the $17^{\text {th }}$ district of Budapest and surrounding settlements)
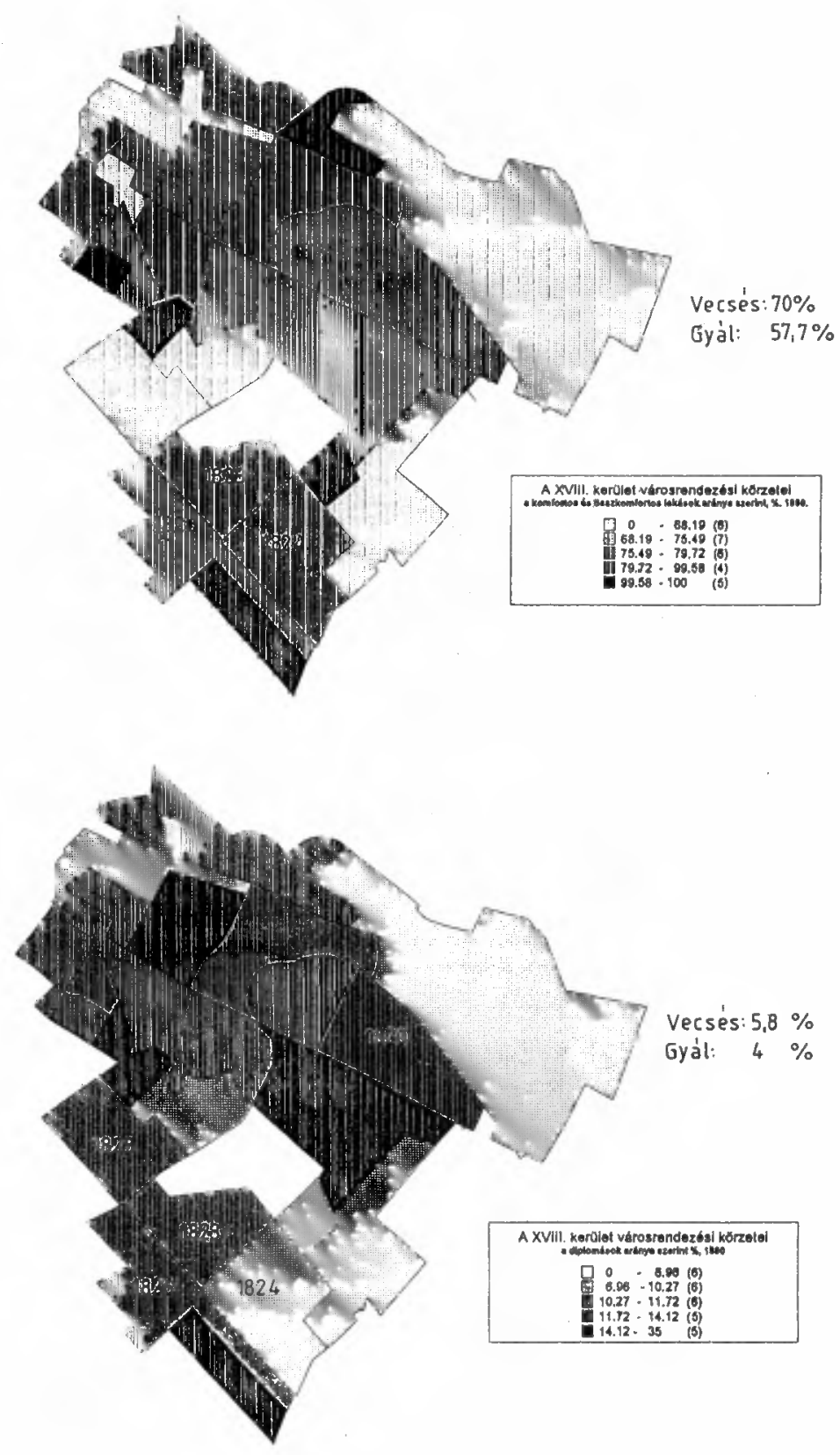


\section{Záró gondolatok}

Az agglomerációk kialakulása, az urbanizáció és a települések fejlődése rendkívül összetett folyamat. Az egyes társadalmi mozgások, a társadalom térbeni szerkezetének változásai jól tủkrözik a telepủlési viszonyokat. A budapesti agglomeráció "történetének" egyik legjelentősebb állomása volt az 1950. évi közigazgatási reform. Az azóta eltelt négy évtized változásait nagyon jól tükrözik azok a mutatók, amelyek alkalmasak mind a minöségi, mind a mennyiségi változások kimutatására. A városfejlỏdés nemcsak az adott településen mutatható ki, hanem annak környékén is. Budapest fejlödését és annak regionális különbségeit jól szemlélteti a fent bemutatott három példa. A határmenti folyamatok kicsiben példázzák a budapesti agglomeráció fejlödésének regionális különbségeit. A csatolás óta eltelt négy évtized alatt fejlődésük eltérő utat járt be, s ez hatással volt a szomszédos településekre is. Ennek hatásai a következőkben foglalható össze:

Az 1950-ben Budapesthez csatolt területek az elmúlt évtizedek alatt szerves részeivé váltak a fövárosnak. Infrastruktúrájuk gyorsan javult, népességük duzzadt, javultak az életminőség mutatói. Mindhárom területen megfigyelhetỏ volt az "anya-kerülethez" való hasonulási folyamat megindulása, amely azonban jelentős területi különbségeket mutat. Azokon a területeken, így például az északnyugati részen (II. kerület és környéke), amelyek korábban is a föváros fejlettebb részeihez tartoztak, a csatolás utáni fejlődés nagyon gyorsan megindult. Ez a gyors fejlödési folyamat nemcsak a becsatolt településre hatott, hanem a szomszédos, a jelenlegi határon kívül eső területekre is. Ugyanakkor ennek ellenpéldájaként - a délkeleti régióban nem játszódott le ez a folyamat. Ennek oka az, hogy a délkeleti régió korábbi elmaradottsága miatt nem tudott nagy hatást gyakorolni a szomszédaira. Az átmenetet az északi terület képviseli, ahol a fejlödés és felzárkózás megindult, de mértéke nem éri el a budai részen tapasztaltat. Mindezek alapján tehát elmondható, hogy a szomszédság, mint hatótényezỏ nagyon nagy mértékben meghatározza a fejlődés és felzárkózás ütemét és irányát. A vázolt társadalmi folyamatok, a települések fejlödése és felzárkózása, átalakulása tehát nem annyira a közigazgatási határokhoz kötött, hanem sokkal inkább az adott térség, a szomszédság jellemzőihez.

\section{Jegyzetek}

' Budafok, Csepel, Kispest, Pestszenterzsébet, Pestszentlörinc, Rákospalota, Újpest, Albertfalva, Békásmegyer, Budatétény, Cinkota, Mátyásfóld, Nagytétény, Pesthidegkút, Pestszentimre, Pestújhely, Rákoscsaba, Rákoshegy, Rákoskersztúr, Rákosliget, Rákosszentmihály, Sashalom, Soroksár

${ }^{2}$ A fớváros fejlesztése a tơbbi településsel szemben mindig kiemelt, elsörendủ feladata volt a településfejlesztési irányelveknek. Ennek köszönhetően a fỏvároson kívüli területeket kevésbé finanszírozták, mint a föváros határán belül levőket.

${ }^{3}$ A jelenlegi állapot az 1990-es állapotot tukkrözi. A rendelkezésre álló statisztikai, népszámlálási adatok ennek bemutatását teszik lehetóvé.

4 A telepulés egy ,zsákutcában" húzódik, É-ÉNy-i oldalán zárt, hegyekkel körülvett terület, csak egyetlen irányból lehet megközelíteni.

${ }^{5}$ A komfortos és összkomfortos lakásokat összevontan ábrázolja a térkép. A két komfortfokozat között csak a fütési módban van eltérés. A komfortos lakások egyedi, az összkomfortos lakások kőzponti fütéssel ellátottak. 
${ }^{6}$ A diplomások arány a 24 éves és idősebb népességbỏl.

${ }^{7}$ A legutóbbi évtized nagy építkezése a Káposztásmegyer 1,2 lakótelep volt, $\mathrm{s}$ ez elengedhetetlenné tette a kőzlekedés fejlesztését is. Így épült meg az észak-déli metróvonal újpesti szakasza az egykori városközpontig. A káposztásmegyeriek utazása ezzel sem oldódott meg, hiszen Újpest-kőzponttól nem épưlt tovább a metró.

${ }^{8} \mathrm{Nem}$ állnak rendelkezésre telepulési szintnél részletesebb adatok, így a várost csak egységes egészként tudjuk elemezni.

${ }^{9}$ Az újpesti lakosok jelentős része nem a kerületben, hanem a fơváros más részein dolgozik, így mindennap kerulet-kőzi ingázásra kényszerül.

10 1942-ben felmerült Vecsés Budapesthez történő csatolása. Szendy Károly elképzelése szerint a település Nagy-Budapest része lett volna. Végall 1950-ben mégis őnállósága mellett döntőttek.

"Gyálra elsősorban az ország keleti részéböl kőltőzőtt a lakosság. A rendelkezésre alló hatalmas beépítetien terület lehetővé tette az elsősorban a fövárosi iparban dolgozó rétegek letelepedését.

12 Csanádi G. és Ladányi J. 1992-ben végzett vizsgálata kimutatta, hogy az imrei terület a föváros legalacsonyabb státuszú területei közé tartozik, a legmagasabb iskolai végzettséget tekintve.

\section{Irodalom}

A Magyar Népköztársaság Minisztertanácsának 4349/1949. (264) M.T. számú rendelete

Berényi I. (1992) Az alkalmazott szociálgeográfia elméleti és módszertani kérdései. Földrajzi tanulmányok, 22. Akadémiai Kiadó, 47. o.

Csanádi G. - Ladányi J. (1992) Budapest térbeni-társadalmi szerkezetének változásai. Akadémiai Kiado, Budapest. 133. o.

Rechnitzer J. (szerk.) (1994) Fejezetek a regionális gazdaságtan tanulmányozásához. MTA RKK. Györ, 200. o. Sárfalvi B. (1991) Magyarország népességföldrajza. Tankönyvkiadó, Budapest. 58. o.

Szabó Z. (1941) Szerelmes földrajz. Nyugat Kiadó és Irodalmi Rt., Budapest

A tanulmány az F015725 sz. OTKA pályázat támogatásával készült.

\section{Abstract}

In accordance with Act XXVI of 1949, 23 settlements ( 7 towns and 16 villages) were joined up with the area of Budapest. Having lost the independence of self goverment, these settlements started to develop along a completely new course, as a consequence of wich they have become an integral part of the capital over the past decades. At the same time, due to the local goverment reforms of 1950, 25 settlements ( 4 towns and 21 villages) became immediate neighbours of the capital.

Along both sides of the current local goverment boundaries, an unusual zone can be found. The inner parts consist of areas which before 1950 were independent and lay in in the shadow of the capital, whereas today they constitute whole districts or parts of districts of the capital itself. On the other side of the border the settlements are in a similar situation to those that were independent before 1950 .

Surveys of settlements are usually adapted to local goverment boundaries. A boundary on the other hand is not on every case a dividing line, it often links neighbouring areas. The survey of the capital's border settlements and the presentation of the dividing and joining qualities of the boundaries is also necessary in the study of the capital's agglomeration. The three "model" areas (the north-west, north east and south east) have been demonstrating diverse trends of development in the various social and sociogeographic tendencies adapt to boundaries. Is the local goverment boundary a real "living" boundary, and do the individual social patterns adapt to artificial frontiers? 